\title{
Effects of novobiocin and methotrexate on the benthic amphipod Ampelisca brevicornis exposed to spiked sediments
}

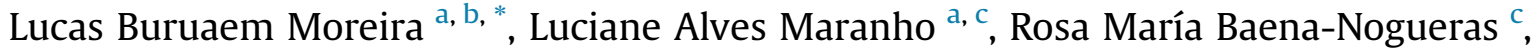 \\ Pablo Antonio Lara-Martín ${ }^{c}$, Maria Laura Martín-Díaz ${ }^{\mathrm{c}}$ \\ a São Paulo State University “Júlio de Mesquita Filho", Bioscience Institute. Pça. Infante D. Henrique, 11330-900, São Vicente, Brazil \\ ${ }^{\mathrm{b}}$ Marine Sciences Institute, Federal University of Ceará, Fortaleza, 60165-081, Brazil \\ c Physical Chemistry Department, Faculty of Marine and Environmental Sciences, University of Cádiz, Puerto Real, 11510, Cádiz, Spain
}

\section{A R T I C L E I N F O}

\section{Article history:}

Received 16 August 2016

Received in revised form

25 October 2016

Accepted 1 November 2016

Available online 2 November 2016

\section{Keywords:}

Sediment bioassay

Biomarker

Pharmaceuticals

Benthos

Marine pollution

\begin{abstract}
A B S T R A C T
The marine amphipod Ampelisca brevicornis was used as model organism of benthic macrofauna to assess the possible adverse effects of pharmaceuticals bound to sediments. Organisms were exposed to sediment spiked with novobiocin (NOV) and methotrexate (MTX) for 10 days in order to estimate the acute toxicity (lethal effects) produced by the two compounds. The surviving organisms were pooled and analyzed to determine their sublethal responses associated with different phases of metabolism (enzyme activities in phases I and II), oxidative stress (antioxidant enzyme activities and lipid peroxidation), and genotoxicity (DNA damage in the form of strand breaks). No lethal or sublethal effects were observed in the amphipods exposed to NOV. For organisms exposed to sediments spiked with MTX the results were found to calculate the concentration that was lethal to $50 \%$ of the organisms exposed in the toxicity tests $\left(\mathrm{LC}_{50}\right.$ of $\left.30.36 \mathrm{ng} / \mathrm{g}\right)$. MTX also induced the metabolism of enzyme detoxification activities in phases I and II. Oxidative stress and DNA damage in particular were also observed, indicating responses associated with MTX's mechanism of action. Both mortality and the set of applied biomarkers allowed for the assessment of bioavailability, oxidative stress, and genotoxicity of NOV and MTX. The information obtained in this investigation can assist in ecological risk assessment of marine sediments contaminated by pharmaceuticals.
\end{abstract}

(c) 2016 Elsevier Ltd. All rights reserved.

\section{Introduction}

Marine environments have been the main destination of large amounts of substances from anthropogenic activities. As a consequence of population growth and human occupation in coastal zones, the presence of intensively used compounds such as human and veterinary pharmaceuticals (PhAs) has increased in these environments. Unlike classical pollutants, PhAs are biologically active chemicals that are designed to interact with a specific receptor in the target organism, be it human or animal (Meredith-Williams et al., 2012). Their biological effects on non-target organisms at environmentally relevant concentrations make them harmful pollutants and a relevant topic in environmental risk assessments, or

\footnotetext{
* Corresponding author. Núcleo de Estudos em Poluição e Ecotoxicologia Aquática, (NEPEA), UNESP. Pça. Infante D. Henrique s/nº, CEP: 11330-900, São Vicente São Paulo, Brazil.

E-mail address: lburuaem@gmail.com (L.B. Moreira).
}

ERAs (Santos et al., 2010; Gaw et al., 2014).

Most PhA compounds are excreted after use and enter sewage treatment plants, where they are degraded, adsorbed in sewage sludge, or released into receiving waters due to inefficient removal treatment (Santos et al., 2010). It is through these methods that they reach coastal zones and marine environments. Recently, advances in the analytical methods used to detect environmental chemistry have allowed us to spot the occurrence of even low levels of $\mathrm{PhAs}$ in marine environments, including seawater, porewater, sediment, and the biota (Lara-Martín et al., 2014; Fabbri and Franzellitti, 2016). Special attention must be given to sediments because they are recognized as both a destination and a secondary source of contaminants for the water column and for the benthic biota (Burton and Johnston, 2010).

Since the identification of PhAs as environmental contaminant, several studies have compiled ecotoxicological data on their toxicity to aquatic organisms in order to provide information for ERAs and guidance for pollution management practices involving 
different classes of compounds, including analgesics, antiinflammatories, antibiotics, beta-blockers, antiepileptic drugs, antidepressants, antitumor agents, and steroidal hormones (Santos et al., 2010; Fong and Ford, 2014; Fabbri and Franzellitti, 2016). Many of these studies consider the effects of PhAs on marine benthic organisms, but they have focused on waterborne exposure. In the case of sediment exposure, the biological effects of PhAs in spiked sediment have been assessed through short-term bioassays using polychaetes (Méndez et al., 2013; Maranho et al., 2014b; Fonseca et al., 2017; Pires et al., 2016) and amphipods as models (Maranho et al., 2014a).

Amphipods constitute an important group of soft-bottom communities of marine environments and vary in their feeding methods and strategies. They are involved in nutrient cycling and in the degradation and redistribution of organic matter in these environments, and they occupy different levels of the marine food web. They are also highly sensitive to any stress in the benthic environment, including the presence of contaminants (CasadoMartínez et al., 2006; Kennedy et al., 2009; Dauvin et al., 2016).

Spiking consists of adding a compound of interest to a sediment for experimental purposes and exposing selected organisms to a range of concentrations in an attempt to establish causal relationships between chemicals and biological responses, which include mortality, reproduction, and sublethal responses (USEPA, 1994, 2001). Most approaches to the assessment of chronic effects include the evaluation of biomarkers, effects which can be defined as a change in biological response at the sub-individual level and which indicate a deviation from the normal status that is not typically detected in healthy organisms (Van Gestel and Van Brummelen, 1996). These responses are associated with the toxic effects of exposure to chemicals at low levels of biological organization, and this information is useful for predicting changes at higher levels, such as populations, communities, and/or ecosystems (Martín-Díaz et al., 2004).

The most commonly employed biomarker approach is the use of biochemical response assessments to measure the activities of detoxification enzymes. The detoxification pathway involves a series of enzymes that are divided into phase I (biotransformation) and phase II (conjugation). Phase I consists of the biotransformation of chemicals via oxidative reactions catalyzed by mixedfunction oxygenase (MFO), a group of enzymes which includes cytochrome P450, or CYP 450 (Van der Oost et al., 2003). Phase II is largely described by the activity of the glutathione-S-transferase (GST) enzyme. This activity involves the conjugation of compounds modified by biotransformation mechanisms (those of phase I) with reduced glutathione, thus facilitating their dissolution in an aqueous medium and allowing for excretion (Schlenk et al., 2008). Exposure to xenobiotics has been associated with an increase in internal levels of reactive oxygen species (ROS) such as peroxides $\left(-\mathrm{H}_{2} \mathrm{O}_{2}\right)$, superoxide $\left(\mathrm{O}^{-}\right)$, and the hydroxyl radical $\left(\mathrm{OH}^{-}\right)$, an increase which causes oxidative stress, lipid peroxidation (LPO), and DNA damage and which can therefore lead to cell death (Regoli and Giuliani, 2014).

Thus, this study sought to assess the lethal and sublethal effects of pharmaceutical-spiked sediments on the amphipod Ampelisca brevicornis. This species recently proved to be a good bioindicator for assessing the effects of other PhAs, such as carbamazepine, ibuprofen, fluoxetine, 17a-ethynylestradiol, propranolol, and caffeine, on sediment samples (Maranho et al., 2014a). In this study, the antibiotic novobiocin (NOV) and the antitumor and cytotoxic drug methotrexate (MTX) were selected as compounds of interest due to their specific usage, their occurrence in effluents from hospitals and waste water from sewage treatment plants, and their toxic effects on organisms, as previously assessed in waterborne exposures (Aguirre-Martínez et al., 2013a, 2013b, 2016). Lethal effects were assessed through ten-day whole sediment toxicity testing, and the sublethal responses were evaluated using a range of biomarker responses as the endpoint. These responses included enzyme activity in phase I (ethoxyresorufin-O-deethylase) and in phase II (GST), oxidative stress (glutathione peroxidase and glutathione reductase), LPO, and DNA damage.

\section{Materials and methods}

\subsection{Test organism: selection, sampling and maintenance}

The amphipod Ampelisca brevicornis is typical of shallow coastal waters in Southern Europe and has a cosmopolitan distribution, extending to the Atlantic coasts of Africa and mainly occurring in fine sediments (Hastings, 1981). The choice of this species as a model and test organism was based on its sensitivity to contaminants, the ease of collection in the field and of maintenance in the laboratory, its frequency in southwestern Spain, and its widespread use in previous whole sediment tests assessing contaminated sites and characterizing dredged material (Riba et al., 2004; CasadoMartínez et al., 2006).

Amphipods were collected through the use of a sieving process: water and sediment were sieved through a $0.5 \mathrm{~mm}$ mesh in an intertidal zone of a clean area in the Bay of Cadiz in southwestern Spain. The amphipods retained on the sieve were rinsed in polyethylene buckets containing seawater, which were then transported to the laboratory and transferred into 10-L glass aquariums containing approximately $3 \mathrm{~cm}$ of sediment from the sampling site and then filled with natural and clean seawater. After sampling, the amphipods were acclimatized in the laboratory for ten days before exposure to the same conditions of salinity (35), temperature $\left(25 \pm 2{ }^{\circ} \mathrm{C}\right)$, and photoperiod (16:8 light:dark) as those used in the experiments.

\subsection{Preparation of pharmaceutical-spiked sediments}

The control sediment was collected from the Rio San Pedro $\left(36^{\circ} 23^{\prime}-37^{\prime} \mathrm{N}, 6^{\circ} 8^{\prime}-15^{\prime} \mathrm{W}\right)$, a salt marsh creek located in the Bay of Cadiz, which is part of the Bahía de Cádiz Natural Park in southwestern Spain. This location is often used as a reference site in pollution studies (Basallote et al., 2012; De Orte et al., 2013), including studies considering biomarker response (Maranho et al., 2014a,b, 2015, Solé et al., 2009; Pérez et al., 2004; Silva et al., 2012). In the laboratory, sediments were sieved in $0.5 \mathrm{~mm}$ mesh to remove solid particles and local macrofauna. Next, the sediments were dried at $70{ }^{\circ} \mathrm{C}(\mathrm{OECD}, 2000)$, disaggregated, and stored at $4{ }^{\circ} \mathrm{C}$ until the spiking procedure. The physicochemical characteristics of the reference sediment are listed in Table 1 . Sediment grain size was analyzed according to the methodology recommended by the United States Geological Survey (2013). Total organic carbon (TOC) and organic matter (OM) content were determined following the methods reported by the USEPA (2001).

Before the spiking procedure, the same volume of seawater lost was added back to the sample. Overlying seawater was obtained from the Cultivos Marinos Experimental Marine Aquaculture Plant at the University of Cádiz. This water has been used for the culture and maintenance of test organisms (fish, mollusks and plankton)

Table 1

Physicochemical properties of sediment used in the pharmaceutical spiking procedure.

\begin{tabular}{llllll}
\hline Variable & Gravel & Sand & Mud (silt + clay) & OM & TOC \\
\hline Percentage (\%) & 0.84 & 57.39 & 41.77 & $8.07 \pm 0.34$ & $1.20 \pm 0.09$ \\
\hline
\end{tabular}


since 2002. Sediment rolling was the method selected for to spike the sediment. In this method, large amounts of sediments spiked with a chemical are mixed in glass jars and homogenized through the use of a jar-rolling apparatus (Poppe et al., 2013; USEPA, 2001). This apparatus consists of a horizontal roll axis powered by an electric motor, which rotates around a metal frame to which twelve parallel jars are attached.

The spiking method used was the adaptation of the ASTM (2000), USEPA (2001), and OECD (2004) protocols published previously by Maranho et al. (2014a). NOV (novobiocin sodium salt product No. N1628) and MTX (Methotrexate hydrate product No. M9929) were purchased from Sigma-Aldrich (Spain) (see Table 2). Both PhAs were dissolved into 0.001\% dimethylsulfoxide (DMSO) (v/v), as recommended by Aguirre-Martínez et al. (2013a, 2013b), by Eades and Waring (2010), and by Quinn et al. (2008a, 2008b). A calculated volume of respective stock solutions was prepared in filtered seawater and injected into each vessel containing approximately $600 \mathrm{ml}$ of dry control sediment in order to achieve the test concentrations at $900 \mathrm{ml}$. The vessels were placed onto the jarrolling machine for $30 \mathrm{~min}$ of mixture time. Next, the vessels were stored in the dark at $4{ }^{\circ} \mathrm{C}$ for 7 days to allow for the partitioning and equilibration of the PhAs into the sediment. After the equilibration period, the spiked sediment was diluted with the reference sediment in order to obtain the concentrations for the bioassay as follows: 1000,100,10, and $1 \mathrm{ng} / \mathrm{g}$ in the case of MTX and $500,50,5$, and $0.5 \mathrm{ng} / \mathrm{g}$ in the case of NOV. Before the experiments began, the sediment was mixed homogeneously with a spoon, and samples were taken for chemical analyses (USEPA, 2001).

\subsection{Determination of pharmaceutical concentrations in spiked sediments}

NOV and MTX concentrations were measured in spiked sediments on the first day of the bioassay following the methods proposed by Jelic et al. (2009) and Baena-Nogueras et al. (2016). Briefly, $2 \mathrm{~g}$ of sediment were placed inside $11 \mathrm{~mL}$ stainless steel cells and extracted at $100{ }^{\circ} \mathrm{C}$ using pressurized liquid extraction and an ASE 200 unit (Dionex) with methanol/water $1 / 2(\mathrm{v} / \mathrm{v})$ as a solvent. After 3 extraction cycles, samples were diluted with water to a final volume of $200 \mathrm{~mL}$ and purified using $500 \mathrm{mg}$ Oasis HLB cartridges (Waters) that had been previously rinsed with methanol and water. Target compounds were extracted using methanol and, after evaporation, samples were reconstituted in methanol/water 25/75 $(\mathrm{v} / \mathrm{v})$.

NOV and MTX concentrations were then determined using ultra-performance liquid chromatography combined with tandem mass spectrometry (UPLC-QqQ-MS/MS) and a Bruker EVOQ system. Target compounds were separated at a flow rate of $0.4 \mathrm{~mL} \mathrm{~min}{ }^{-1}$, and their ionization was performed in positive electrospray ionization mode (ESI+). MRM transitions used to confirm the identity of the precursor ions were $m / z 613.2>189.3, m / z 613.2>133.4$ in the case of NOV and $m / z 455.2>175.2, m / z 455.2>307.1$ in the case of MTX. Methanol was used as mobile phase A, while water with $0.05 \%$ formic acid and $0.06 \%$ ammonium formate were used as mobile phase B. Elution gradient started at $5 \%$ of aqueous mobile phase $A$. The percentage of methanol was then increased linearly to $100 \%$ during the first $5 \mathrm{~min}$ and kept at 100\% over 3 min in positive mode. Total run time was $10 \mathrm{~min}$ and included a re-equilibration time of $2 \mathrm{~min}$. Further details on the methodology can be found in Jelic et al. (2009) and in Baena-Nogueras et al. (2016).

\subsection{Spiked sediment toxicity tests}

Whole sediment toxicity tests were performed as described by Riba et al. (2004), with some modifications. They were performed for all concentrations of the two PhAs, for the controls (with and without DMSO), and for a negative control (using sediment from the amphipod sampling site). The bioassay exposure chambers were mounted in $3 \mathrm{~L}$ glass vessels containing a $5 \mathrm{~cm}$ layer of sediment (approximately $200 \mathrm{ml}$ ) overlaid with approximately $800 \mathrm{ml}$ of filtered clean seawater. Tests were prepared in triplicate for each treatment. Thirty A. brevicornis specimens were exposed to

Table 2

Overview of physicochemical characteristics and structures of MTX and NOV.

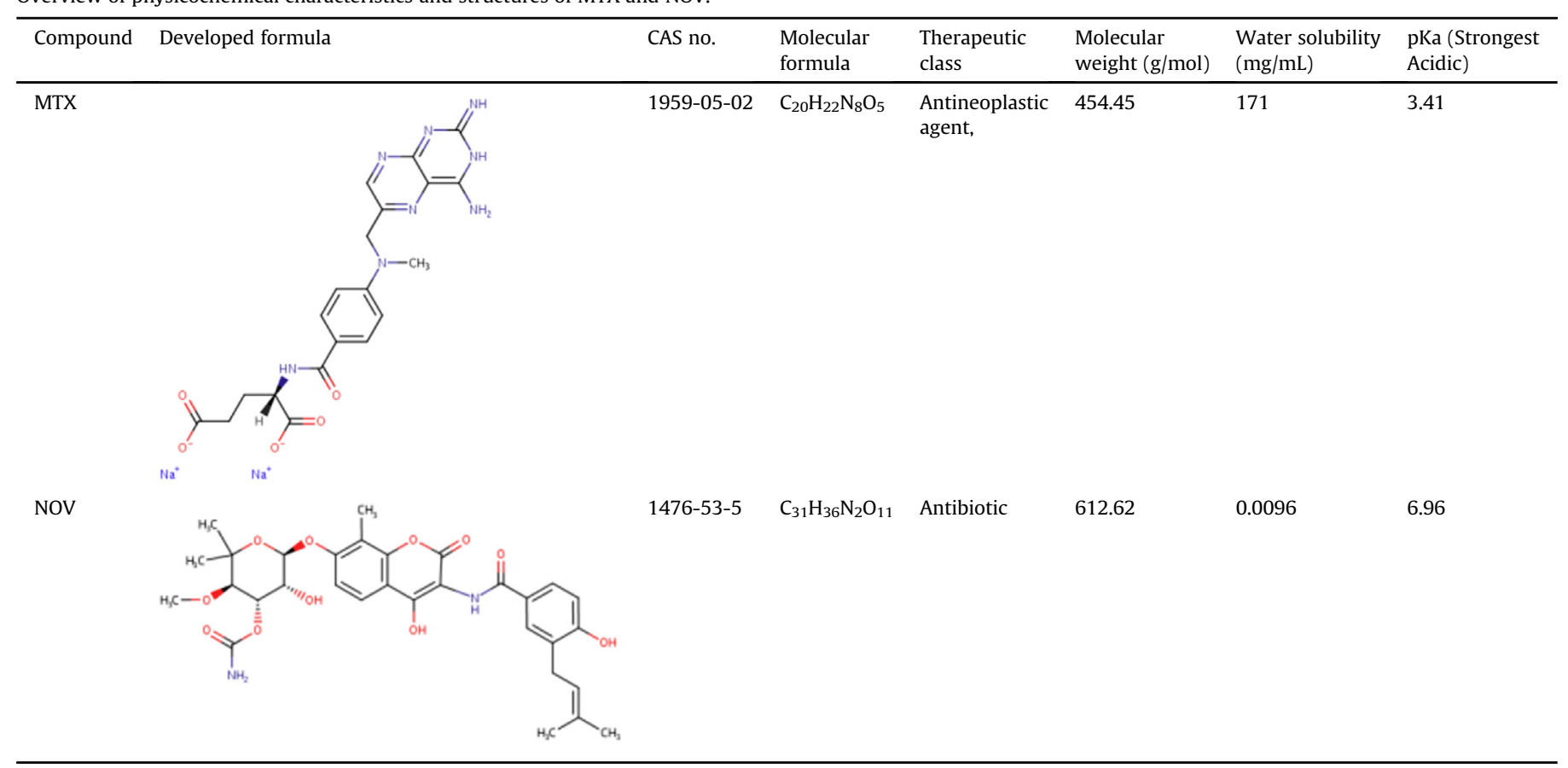

Source: http://www.drugbank.ca/. 
whole sediment, and the overlying water quality parameters (temperature, dissolved oxygen, $\mathrm{pH}$, and salinity) were monitored at the beginning and the end of the test. After the 10-day exposure period, the sediments were sieved and the surviving amphipods were removed, counted, randomly sorted into five pools, and further stored at $-80{ }^{\circ} \mathrm{C}$ for biomarker response analysis. The mortality after 10 days of exposure was used as the acute toxicity endpoint.

Organisms from the same replicate were randomly pooled before homogenization to achieve the number of five replicates per treatment. As part of sample processing for biomarker analysis, each pool of amphipods was homogenized with a tissue homogenizer (Ultra-turrax ${ }^{\circledR}$ ) in a buffer containing $\mathrm{NaCl}$, dithiotreitol, EDTA, and HEPES $(1: 7 \mathrm{w} / \mathrm{v})$. Homogenates were aliquoted to quantify total protein (TP) concentrations and to assess responses as LPO and DNA damage (strand breaks). The remainder was centrifuged $\left(15,000 \times \mathrm{g} ; 4^{\circ} \mathrm{C} ; 20 \mathrm{~min}\right)$, and the supernatant fraction (S15) was aliquoted for the assessment of TP concentrations and of ethoxyresorufin-O-deethylase (EROD), glutathione antioxidant (peroxidase and reductase), and glutathione S-transferase (GST) activities.

\subsection{Biomarker response analysis}

\subsubsection{Quantification of total protein concentration (TP)}

Concentration of TP in the homogenized and S15 fraction of each sample was determined using the Bradford protein assay (Bradford, 1976 ) in order to normalize the biomarker results. Sample aliquots of $20 \mu \mathrm{l}$ were incubated with the Bio-Rad protein assay reagent that had been diluted in distilled water to $1: 4 \mathrm{v} / \mathrm{v}$ (Bio-Rad Laboratories GmbH Cat. no. 5000-0006) and incubated for $5 \mathrm{~min}$. Absorbance was read on a microplate reader at $595 \mathrm{~nm}$. Total protein (TP) concentration was calculated based on a bovine serum albumin (BSA) standard curve, and results were expressed as $\mathrm{mg} / \mathrm{mL}$.

\subsubsection{Ethoxyresorufin-O-deethylase (EROD) activity}

EROD is an enzyme of the CYP 450 monooxygenase 1A group (a CYP1A-like enzyme) from phase I metabolism and MFO activity for the 7-hydroxyresorufin substrate. EROD activity was measured using the methodology described by Gagné and Blaise (1993). As per this method, enzyme activity in $50 \mu \mathrm{L}$ of S15 was determined based on the transformation rate of $10 \mu \mathrm{M}$ of a 7-ethoxyresorufin substrate in 7-hydroxyresorufin via EROD-mediated deethylation. This reaction was initiated by the addition of $1 \mathrm{mM}$ reduced NADPH

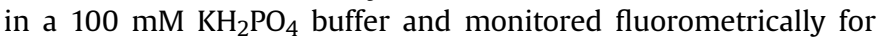
$60 \mathrm{~min}$ using $516 \mathrm{~nm}$ (excitation) and $600 \mathrm{~nm}$ (emission) filters. The fluorescence of each sample was transformed using a 7hydroxyresorufin standard calibration curve, and the results were expressed in $\mathrm{pmol} / \mathrm{min} / \mathrm{mg}$ of total protein.

\subsubsection{Glutathione S-Transferase (GST) activity}

As described above, GST is involved in phase II metabolic pathways. The procedure utilized to determine GST activity was adapted from McFarland et al. (1999), in which enzyme activity was analyzed using $42 \mathrm{mM}$ 1-chloro-2,4-dinitrobenzene (CDNB) and $1 \mathrm{mM}$ GSH as substrates. and the enzyme activity measured spectrophotometrically at $340 \mathrm{~nm}$ every $30 \mathrm{~s}$ for $3 \mathrm{~min}$. Results were expressed as $\mathrm{nmol} / \mathrm{min} / \mathrm{mg}$ of total protein.

\subsubsection{Glutathione peroxidase (GPx) activity}

GPx plays an important role in the catalysis of $\mathrm{H}_{2} \mathrm{O}_{2}$ to water through the oxidation of reduced GSH to its oxidized form, GSSG (Van der Oost et al., 2003). As part of the GPx assay (McFarland et al., 1999), GPx activity was measured spectrophotometrically using $1 \mathrm{mM}$ cumene hydroperoxide as a substrate in a buffer $(\mathrm{pH} 7)$ containing $50 \mathrm{mM}$ potassium phosphate, $0.1 \mathrm{mM}$ EDTA and $0.15 \mathrm{mM}$ sodium azide. A decrease in NADPH absorbance, measured at $340 \mathrm{~nm}$ during the oxidation of NADPH to NADP, was indicative of GPx activity. Results were expressed as $\mathrm{nmol} / \mathrm{min} / \mathrm{mg}$ of total protein.

\subsubsection{Glutathione reductase (GR) activity}

The activity of GR enzyme was observed as the measurement of reduced glutathione $(\mathrm{GSH})$ regeneration. Absorbance $(340 \mathrm{~nm})$ was measured every 2 min for $10 \mathrm{~min}$. GR activity was expressed as $\mathrm{pmol} / \mathrm{min} / \mathrm{mg}$ of total protein.

\subsubsection{Lipid peroxidation}

Thiobarbituric acid reactive substances (TBARs) constitute intermediate products of LPO generated by free radical production in oxidative stress (Janero, 1990). LPO products were measured in homogenates using the thiobarbituric acid method (Wills, 1987). Samples were incubated in $10 \%$ trichloroacetic acid (TCA) containing $1 \mathrm{mM} \mathrm{FeSO}_{4}$ and $0.67 \%$ thiobarbituric acid (TBA), and the solution was mixed and heated at $70-80^{\circ} \mathrm{C}$ for $10 \mathrm{~min}$. The samples were then centrifuged to remove the precipitate $(10,000 \times g$ for $10 \mathrm{~s}$ ) and measured fluorometrically at $516 \mathrm{~nm}$ (excitation) and at $600 \mathrm{~nm}$ (emission). Concentrations were calculated based on a standard curve of tetraethoxypropane, and results were expressed as nmol of TBARS/mg of total protein.

\subsubsection{DNA damage}

DNA damage was measured as the formation of strand breaks, which were themselves assessed using the alkaline precipitation assay (Olive, 1988). Samples were mixed with a buffer containing 2\% SDS, $10 \mathrm{mM}$ EDTA, $10 \mathrm{mM}$ Tris-base and $40 \mathrm{mM} \mathrm{NaOH}$. After the sample was mixed for $1 \mathrm{~min}, 12 \mathrm{M} \mathrm{KCl}$ was added. The solution was then heated for $10 \mathrm{~min}$ at $60{ }^{\circ} \mathrm{C}$ and then mixed using inversion, cooled at $4{ }^{\circ} \mathrm{C}$ for $30 \mathrm{~min}$, and centrifuged at $4{ }^{\circ} \mathrm{C}(8000 \times \mathrm{g})$ for $5 \mathrm{~min}$. This procedure allowed for the precipitation of the genomic DNA linked to SDS-associated nucleoproteins (Martín-Díaz et al., 2009). One hundred nM of Hoescht dye was added to the supernatant, and fluorescence was measured at $360 \mathrm{~nm}$ (excitation) and at $450 \mathrm{~nm}$ (emission). DNA concentrations were determined using salmon sperm genomic DNA standards, and the results expressed as $\mu \mathrm{g}$ of supernatant DNA/mg of total protein.

\subsection{Statistics}

The linear interpolation method (Norberg-King, 1988) was used to calculate the lethal concentration for $50 \%$ of $A$. brevicornis exposed in the toxicity tests $\left(\mathrm{CL}_{50} ; 10\right.$ days). Based on acute toxicity and biomarker response, the hypothesis was that the amphipods would be significantly affected by exposure to the pharmaceutical concentrations in the spiked sediments. This hypothesis was statistically tested using Analysis of Variance (ANOVA). First, the data was analyzed for normality and for homoscedasticity using the Shapiro-Wilk test and Bartlett's test, respectively. A one-way ANOVA followed by the Bonferroni's multiple comparisons test were employed to identify any concentrations that differed significantly from the control (including the DMSO and the negative control). In order to determine relationships between sediment toxicity (mortality) and biomarker responses a matrix was constructed and a Pearson's $r$ correlation coefficient was calculated using the median values of each set of data (biomarkers and toxicity). The significance levels were set at 0.05 and 0.01 for the ANOVA and at 0.05 for the correlation analysis. 


\section{Results and discussion}

The spiking method produced a recovery of $83 \%$ in the case of MTX and $100 \%$ in the case of NOV (Table 3). According to Site (2001), the sorption of the chemical of interest in solid and sediments is associated with key parameters of the compound in question, including water solubility, the octanol/water partition coefficient, vapor pressure, Henry's law constant, the adsorption coefficient, and the bioconcentration factor. Solid matrix properties such as characteristics of fine particles, type of OM, TOC, as well as environmental variables such as $\mathrm{pH}$ and $\mathrm{Eh}$, are also involved in the sorption and desorption processes (Site, 2001; Huang et al., 2003). Information on physicochemical properties of $\mathrm{PhAs}$ and their sorption and desorption behaviors have been published (LaraMartín et al., 2015), but there is no data available on NOV or MTX. Thus, the low water solubility and the recovery results were used to assume the expected sediment-bound exposure of organisms in the bioassay for the concentrations of both PhAs (see Table 4).

No significant differences were observed in the comparison between the sediment from the control (reference) and the solvent control (DMSO-spiked sediment at $0.001 \% \mathrm{v} / \mathrm{v}$ ) (Fig. 1). MTX-spiked sediments caused significant amphipod mortality when rates were considered to those of the control at 10,100, and $1000 \mathrm{ng} / \mathrm{g}$. The data was fitted to a non-linear model and produced an $\mathrm{LC}_{50}$ of $30.36 \mathrm{ng} / \mathrm{g}$ (5.1-182.1; 95\% confidence intervals of $\mathrm{LC}_{50}$ ). Significant amphipod mortality was not observed in the NOV-spiked sediments.

As is the case of geochemical behavior, there are few studies addressing the toxicity of these two compounds in marine organisms, especially using sediment samples, which makes further comparison of the results unfeasible. Aguirre-Martínez et al. (2016) assessed acute toxicity of MTX in seawater samples using bioluminescence analysis on Aliivibrio fischeri. They also assessed growth inhibition of the microalga Isochrysis galbana and embryo-larval development of the sea urchin Paracentrotus lividus. The results revealed that MTX was not toxic to any of the models or at any of the environmental concentrations tested. NOV toxicity was also assessed by Aguirre-Martínez et al. (2015), and the results showed a significant decrease in bioluminescence of the bacterium $A$. fischeri, significant growth inhibition of I. galbana, and effects on fertilization and embryo-larval development in P. lividus. These results were in contrast to those of the growth inhibition of Pseudokirchneriella subcapitata, to which NOV was not toxic.

The ecological risks of both compounds were assessed based on measured environmental concentration (MEC) and the predicted no-effect concentration (PNEC) index. In these assessments, MTX was not found to be harmful to the marine species tested and was thus found to pose no risk to the environment (Aguirre-Martínez et al., 2016). Environmental concentrations of NOV, however, were found to pose ecological risks (Aguirre-Martínez et al., 2015). The limited knowledge on the behavior of both compounds in complex matrices such as sediments and the lack of environmental concentration studies also makes it difficult to properly assess environmental risk.

In the phase I and II biomarker assessment, EROD activity was found to have increased significantly in the amphipods in the

Table 3

Nominal and measured concentrations of target pharmaceuticals in spiked sediments (ng/g).

\begin{tabular}{llll}
\hline Compound & Nominal concentration & Measured concentration & Recovery \\
\hline MTX & 1000 & 830 & $83 \%$ \\
NOV & 500 & 500 & $100 \%$ \\
\hline
\end{tabular}

sample pools relative to the control when they were exposed to MTX (100 and $1000 \mathrm{ng} / \mathrm{g}$ ), whereas neither DMSO nor NOV resulted in significant increases. A significant increase in GST activity was observed only in organisms exposed to $1000 \mathrm{ng} / \mathrm{g}$ of MTX-spiked sediment exposure (Fig. 2).

The results of the oxidative stress biomarker assessment showed that GR activity also increased only in $1000 \mathrm{ng} / \mathrm{g}$ of MTX compared to the control. The amphipods exposed to MTX exhibited significant increases in GPx activity at $1 \mathrm{ng} / \mathrm{g}$ and $10 \mathrm{ng} / \mathrm{g}$ and nondetected activity at $100 \mathrm{ng} / \mathrm{g}$ and $1000 \mathrm{ng} / \mathrm{g}$. The results of the biomarkers of effect showed that amphipods exposed to $100 \mathrm{ng} / \mathrm{g}$ and $1000 \mathrm{ng} / \mathrm{g}$ of MTX-spiked sediment presented significantly higher LPO levels and DNA damage than the control.

In order to determine associations between acute toxicity and biomarker responses, a Pearson's correlation coefficient analysis was performed. The analysis revealed significant positive correlations between acute toxicity and all biomarker responses except GPX, which presented a distinct response to MTX, with a significant increase followed by non-detected activity, as mentioned above.

Our results showed that NOV-spiked sediments did not produce lethal biological effects (acute toxicity) or sublethal biological effects (biomarker response) on A. brevicornis. However, AguirreMartínez et al. (2013a,b) found a significant decrease in the lysosomal membrane stability of cells from the Carcinus maenas crab exposed to NOV-spiked seawater for 28 days at 1,10 , and $50 \mu \mathrm{g} / \mathrm{L}$ when they used the neutral red retention assay (NRR). In this case, cell damage in the form of lysosome membrane destabilization may occur as a consequence of exposure to chemicals and is considered an early warning biomarker of stress (Cajaraville et al., 2000). Responses in the form of EROD, GST, and GR activities, along with LPO and DNA damage, were also observed by Aguirre-Martínez et al.(2015) in the digestive gland of the freshwater clam Corbicula fluminea exposed to NOV. These results indicate that stress was caused by this selected antibiotic in the aqueous medium. Thus, due to the low solubility in water of NOV compared to that of MTX, we assume that there is a low bioavailability of NOV in sediment samples obtained from the spiking procedure in the conditions described.

On the other hand, MTX-spiked sediments produced both lethal and sublethal biological effects on $A$. brevicornis. In this case, data will be discussed based on the mode of action (MoA) described for humans and other mammals.

MTX is an antineoplastic agent that is widely used alone or in combination with other drugs for the treatment of a variety of cancers, such as breast cancer, head and neck cancer, osteosarcoma, lymphoma, and acute lymphoblastic leukemia (Barros et al., 2013). The mechanism of action of MTX is to inhibit dihydrofolate reductase (DHFR) by competing with dihydrofolate (DHF) for the active site, thus compromising DNA synthesis; DHFR catalyzes the NADPH-dependent reduction of DHFR to tetrahydrofolate (THF) involved in the biosynthesis of thymidylate, hypoxantine, and glycine (Rader and Huennekens, 1973; Affleck et al., 2006). In this way, the depletion of THF and its derivatives caused by MTX interferes with DNA synthesis and, in doing so, affects the division cycle and proliferation of cells (Barros et al., 2013). These effects are the changes behind cytotoxicity and potential teratogenicity (Affleck et al., 2006).

The primary mechanism by which DHFR inhibition induces cytotoxicity is the resulting inhibition of dTMP synthesis and of the purine precursors required for DNA synthesis (McGuire, 2003). According to the author, the inhibition of these pathways likely occurs through different mechanisms, one of which is the formation and accumulation of single- and double-strand breaks in genomic DNA. They occur because the DNA synthesis in progress is halted and/or because DNA repair continues to remove damaged 
Table 4

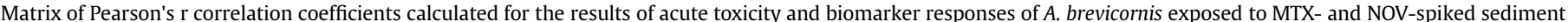
samples.

\begin{tabular}{|c|c|c|c|c|c|c|c|}
\hline & & Toxicity & EROD & GST & GPx & GR & LPO \\
\hline \multirow[t]{2}{*}{ EROD } & $r$ & 0.88 & & & & & \\
\hline & $\mathrm{p}$ value & 0.001 & & & & & \\
\hline \multirow[t]{2}{*}{ GST } & r & 0.88 & 0.90 & & & & \\
\hline & $\mathrm{p}$ value & 0.001 & 0.000 & & & & \\
\hline \multirow[t]{2}{*}{ GPx } & r & -0.14 & -0.35 & -0.04 & & & \\
\hline & $\mathrm{p}$ value & 0.695 & 0.321 & 0.922 & & & \\
\hline \multirow[t]{2}{*}{ GR } & $\mathrm{r}$ & 0.90 & 0.91 & 0.96 & -0.12 & & \\
\hline & $\mathrm{p}$ value & 0.000 & 0.000 & 0.000 & 0.747 & & \\
\hline \multirow[t]{2}{*}{ LPO } & $\mathrm{r}$ & 0.74 & 0.82 & 0.67 & -0.22 & 0.71 & \\
\hline & $\mathrm{p}$ value & 0.014 & 0.004 & 0.033 & 0.535 & 0.022 & \\
\hline \multirow[t]{2}{*}{ DNA damage } & r & 0.86 & 0.93 & 0.82 & -0.34 & 0.82 & 0.81 \\
\hline & $\mathrm{p}$ value & 0.002 & 0.000 & 0.004 & 0.338 & 0.004 & 0.005 \\
\hline
\end{tabular}

Significant correlations are marked in bold $(\mathrm{p}<0.05)$

A

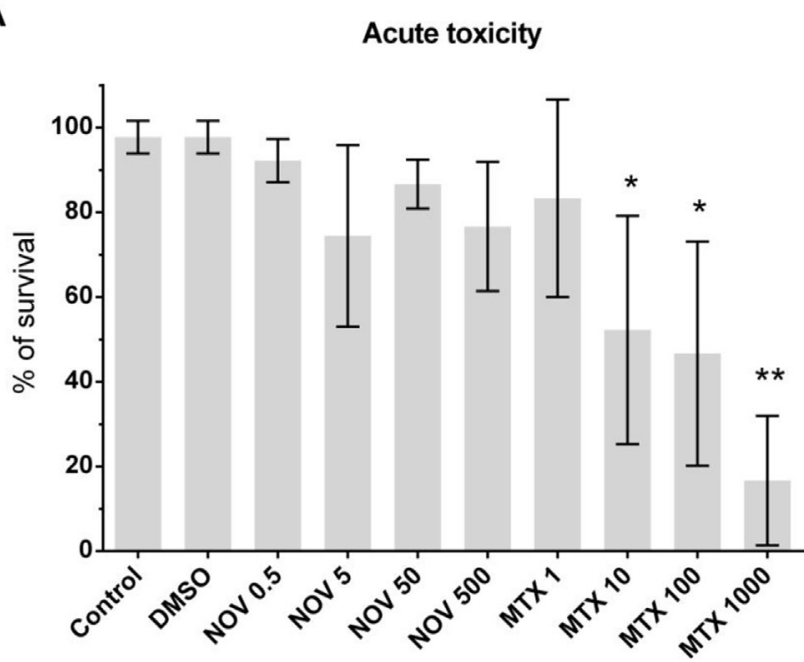

B

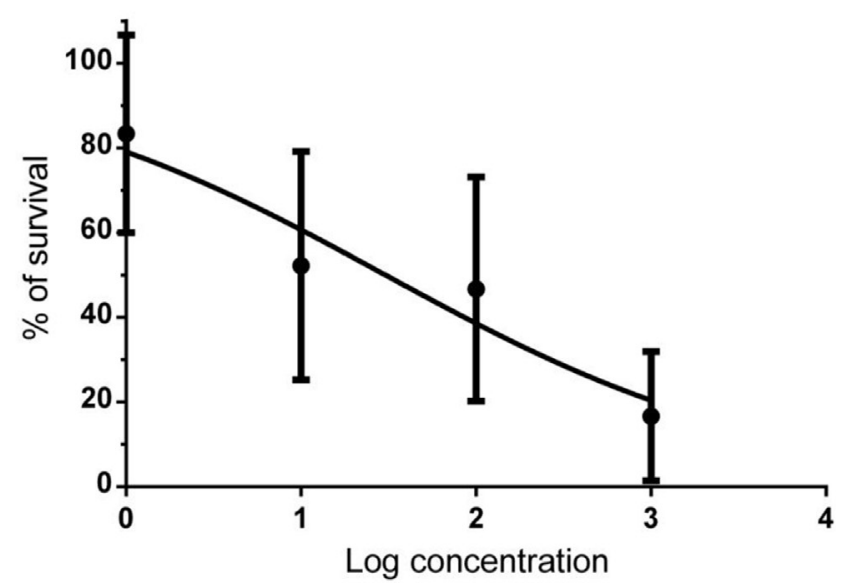

Fig. 1. Results of acute toxicity bioassay (mean and SD; $n=3$ ). A - Survival rates of the amphipod A brevicornis exposed to MTX and NOV spiked in whole sediment samples; B - Non-linear model of MTX results to calculate $\mathrm{LC}_{50}$. Significant differences set at $\mathrm{p}<0.05\left(^{*}\right)$ and $\mathrm{p}<0.01\left(^{* *}\right)$.

bases but cannot properly repair the resulting basic sites due to the deficiency of deoxynucleotide (dNTP); in this case, cell death can occur through either necrosis or apoptosis.
The mechanisms described above are consistent with our results, which showed a significant correlation between toxicity and biomarker responses, including the high levels of DNA damage observed in the organisms exposed to MTX. Following the uptake of xenobiotics by the organism, phase I metabolism is responsible for transforming the compound into a more soluble and easily excreted substance. The activation of CYP-mediated metabolism is involved in the metabolism of pharmaceutical products (Quinn et al., 2004; Maranho et al., 2014a). In rabbits, MTX is converted into 7-OHMTX, its major extracellular metabolite in several tissues, by aldehyde oxidase (ALO). In humans, however, xanthine oxidase (XO) is thought to be more relevant than ALO in this metabolism (Chládek et al., 1997). Guitton et al. (1994) observed a decrease in the activity of the monooxygenase system associated with cytochrome P450 in rats exposed to MTX, but using an in vitro approach, Chládek et al. (1997) observed that there is no direct effect of inhibitory action of MTX on cytochrome P450 or its enzyme actives, including EROD in the liver microsomes of rats and humans.

Increased EROD activity was observed in amphipods exposed to $100 \mathrm{ng} / \mathrm{g}$ and $1000 \mathrm{ng} / \mathrm{g}$ of MTX, a finding which suggests an induction of cytochrome P450 1A-like metabolism. Some authors have argued that there is no evidence in the literature of the occurrence of CYP1 family proteins in crustaceans, but it is possible that the EROD activity detected may have been catalyzed by a cytochrome P450 other than a CYP1A due to the similarity of amino acid sequences (James and Boyle, 1998; Rewitz et al., 2006). Rewitz et al. (2006) reviewed the phylogeny of marine invertebrate P450s and reported that enzymes grouped into Clan 2 (related to CYP2) are the closest relatives to vertebrate CYP1A enzymes and could be responsible for the metabolism of typical substrates of CYP1A enzymes (including ethoxycoumarin) that have been reported in marine invertebrates. Maranho et al. (2014a) observed increased EROD activity in A. brevicornis exposed to the beta-blocker propranolol spiked in sediments at 0.5 and $5 \mathrm{ng} / \mathrm{g}$, and their findings corroborate the induction of CYP1A-like isoenzymes in amphipods exposed to MTX.

GST activity increased at the highest MTX exposure concentration, and this activity was correlated with EROD and GR activities, LPO, DNA damage, and acute toxicity, an association which suggests that phase II metabolism is involved in the conjugation and detoxification of MTX. In a study on human cells, Barros et al. (2013) observed that the induction of GST activity regulates the redox state of cythocrome $C$ in order to prevent MTX cytotoxicity. In marine organisms, the GST enzyme activity has been reported to be affected by xenobiotics in different amphipod species, including Gammarus fasciatus (Gélinas et al., 2013) and Monoporeia affini (Gorokhova et al., 2010). Maranho et al. (2014a) also observed 
EROD
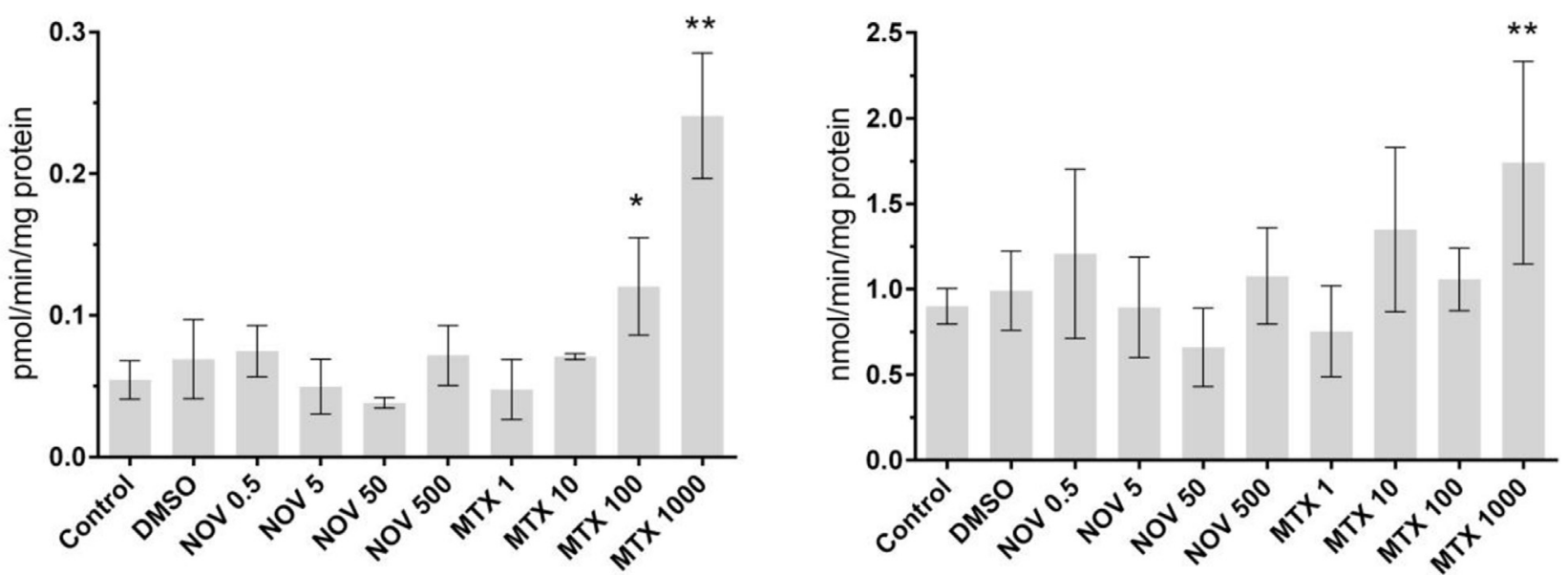

GR
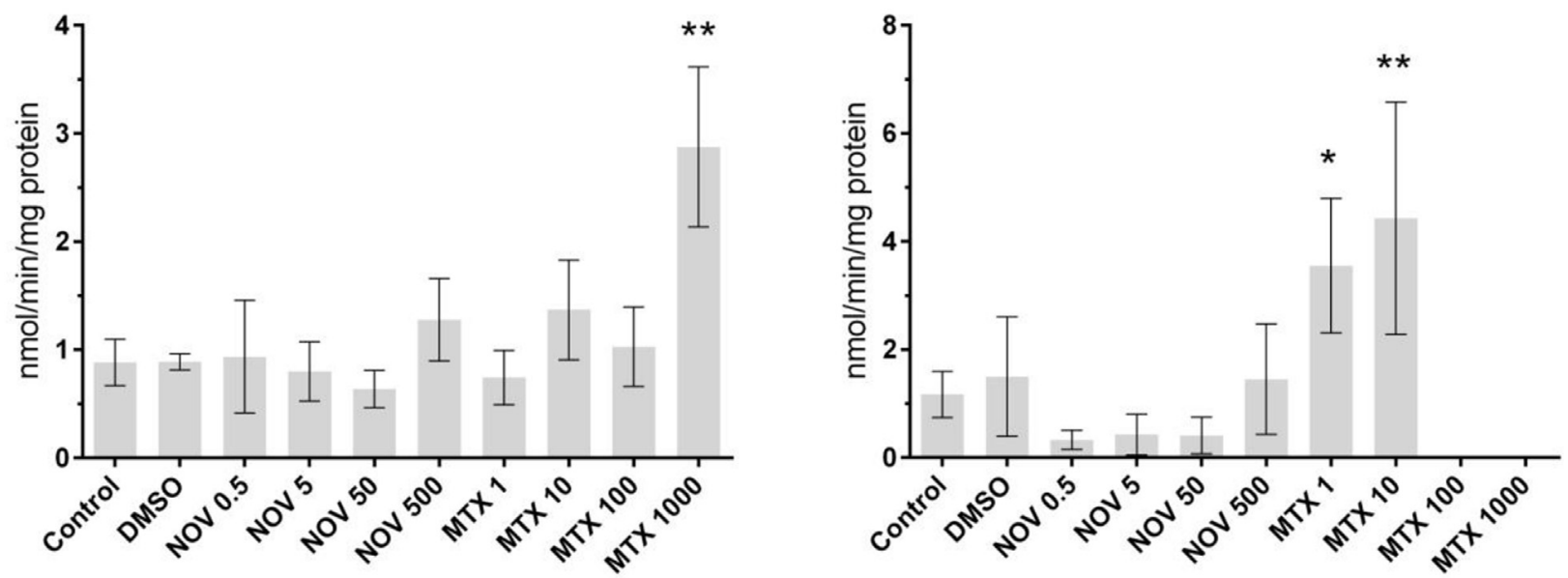

LPO
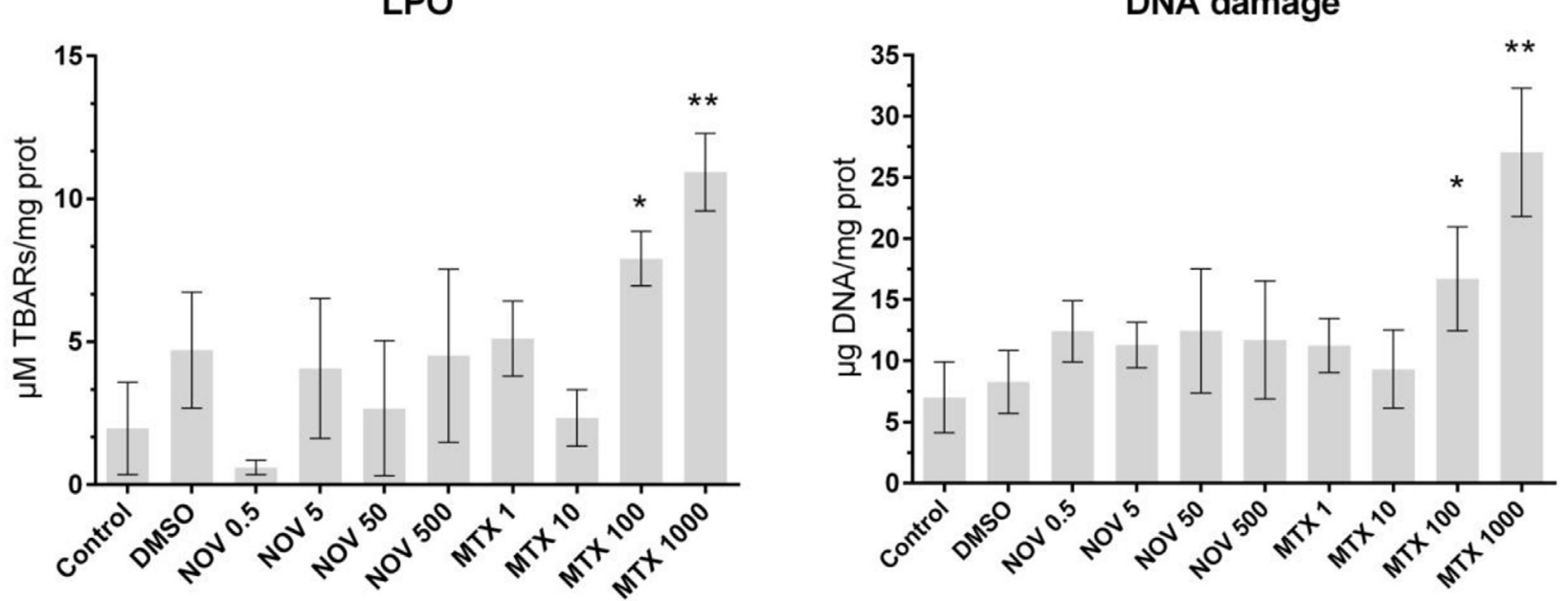

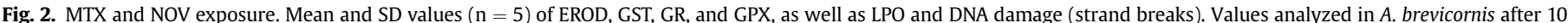
days of laboratory exposure and compared to a reference sediment. Significant difference found after the comparison to the control set at $\mathrm{p}<0.05\left({ }^{*}\right)$ and $\mathrm{p}<0.01\left({ }^{* *}\right)$. 
increased GST activity in A. brevicornis specimens exposed to the anticonvulsant carbamazepine and the anti-inflammatory ibuprofen.

Lastly, antioxidant activity (GR and GPx enzymes) was also affected, a result which indicates that oxidative stress promoted by MTX exposure through the correlation with GR and LPO. Also, no GPX activity was detected in the amphipods exposed to $100 \mathrm{ng} / \mathrm{g}$ and $1000 \mathrm{ng} / \mathrm{g}$ of MTX, a results which likely reflecting the inhibitory effect at these concentrations. In humans, the mechanism of action of MTX can induce apoptosis by cytochrome $c$ release into the cytosol (Barros et al., 2013); once oxidative stress occurs, the peroxidase activity of cytochrome $c$ is activated, leading to an increase in antioxidant responses (Kagan et al., 2005; Belikova et al., 2006).

\section{Conclusion}

The spiking method for sediment toxicity testing and the battery of biomarker assessments combined proved to be an effective tool for assessing sublethal responses in amphipods exposed to pharmaceutical products. It is difficult to directly link the effects at low levels of biological organization (such as biomarker responses) to those expressed at higher levels (such as acute toxicity). However, our results showed significant evidence of effects being associated with the mode of action of MTX as part of the effects of toxicity experienced by the amphipod $A$. brevicornis. Further investigations involving apoptosis and its molecular signaling pathways in marine organisms exposed to MTX can provide relevant information for addressing the environmental impacts of this substance. NOV was not found to be toxic to $A$. brevicornis at the concentrations tested in the present study. In both cases, research into partitioning (especially in the case of NOV) and bioaccumulation will likely complement information on the ecological risk of these substances.

\section{Acknowledgments}

The authors L. B. Moreira and L. A. Maranho would like to thank CAPES/MEC-Brazil for the research internship, the doctoral scholarship and for the partial financial support of this study (grant numbers 5133/11-4 and BEX 0362/10-7). This research was funded by the P09-RNM-5136 Project (Government of Andalusia, Spain) and the European Regional Development Fund (ERDF).

\section{References}

Affleck, J.G., Neumann, K., Wong, L., Walker, V.K., 2006. The effects of methotrexate on Drosophila development, female fecundity, and gene expression. Toxicol. Sci. 89, 495-503.

Aguirre-Martínez, G.V., DelValls, T.A., Martín-Díaz, M.L., 2013a. Identification of biomarkers responsive to chronic exposure to pharmaceuticals in target tissues of Carcinus maenas. Mar. Environ. Res. 87-88, 1-11.

Aguirre-Martínez, G.V., DelValls, T.A., Martín-Díaz, M.L., 2013b. Early responses measured in the brachyuran crab Carcinus maenas exposed to carbamazepine and novobiocin: application of a 2-tier approach. Ecotoxicology Environ. Saf. 97, 47-58.

Aguirre-Martínez, G.V., Owuor, M.A., Garrido-Pérez, C., Salamanca, M.J., Del Valls, T.A., Martín-Díaz, M.L., 2015. Are standard tests sensitive enough to evaluate effects of human pharmaceuticals in aquatic biota? Facing changes in research approaches when performing risk assessment of drugs. Chemosphere 120, 75-85.

Aguirre-Martínez, G.V., Okello, C., Salamanca, M.J., Garrido, C., DelValls, T.A., MartínDíaz, M.L., 2016. Is the step-wise tiered approach for ERA of pharmaceuticals useful for the assessment of cancer therapeutic drugs present in marine environment? Environ. Res. 144, 43-59.

American Society for Testing and Materials (ASTM), 2000. Standard Guide for Collection, Storage, Characterization, and Manipulation of Sediments for ToxIcological Testing, vol. 11.05. Annual Book of ASTM Standards, West Conshohocken, PA, pp. E1391-E1394.

Baena-Nogueras, R.M., Pintado-Herrera, M., González-Mazo, E., Lara-Martín, P.A., 2016. Determination of pharmaceuticals in coastal systems using solid phase extraction (SPE) followed by ultra performance liquid chromatography tándem mass spectrometry (UPLC-MS/MS). Curr. Anal. Chem. 12, 1-19.

Barros, S., Mencia, N., Rodríguez, L., Oleaga, C., Santos, C., Noé, V., Ciudad, C.J., 2013. The redox state of cytochrome $\mathrm{C}$ modulates resistance to methotrexate in human MCF7 breast Cancer cells. Plos One 8, e63276.

Basallote, M.D., Rodríguez-Romero, A., Blasco, J., DelValls, T.A., Riba, I., 2012. Lethal effects on different marine organisms, associated with sediment-seawater acidification deriving from $\mathrm{CO}_{2}$ leakage. Environ. Sci. Pollut. Res. Int. 19, 2550-2560.

Belikova, N.A., Vladimirov, Y.A., Osipov, A.N., Kapralov, A.A., Tyurin, V.A. Potapovich, M.V., Basova, L.V., Peterson, J., Kurnikov, I.V., Kagan, V.E., 2006. Peroxidase activity and structural transitions of cytochrome $\mathrm{c}$ bound to cardiolipin-containing membranes. Biochemistry 45, 4998-5009.

Bradford, M.B., 1976. A rapid and sensitive method for the quantification of microgram quantities of protein utilizing the principle of protein-dye binding. Anal. Biochem. 72, 248-254.

Burton, G.A., Johnston, E.L., 2010. Assessing contaminated sediments in the context of multiple stressors. Environ. Toxicol. Chem. 29, 2625-2643.

Cajaraville, M.P., Bebianno, M.J., Porte, C., Sarasquete, C., Viarengo, A., 2000. The use of biomarkers to assess the impact of pollution in coastal environments of the Iberian Peninsula: a practical approach. Sci. Total Environ. 247, 295-311.

Casado-Martínez, M.C., Beiras, R., Belzunce, M.J., González-Castromil, M.A., MarínGuirao, L., Postma, J.F., Riba, I., DelValls, T.A., 2006. Inter-laboratory assessment of marine bioassays to evaluate environmental quality of coastal sediments in Spain: III. The whole sediment toxicity test using crustacean amphipods. Cienc. Mar. 32, 149-157.

Chládek, J., Martínková, J., Šišpera, L., 1997. An in vitro study on methotrexate hydroxylation in rat and human liver. Physiol. Res. 46, 371-379.

Dauvin, J.C., Andrade, H., de-la-Ossa-Carretero, J.A., Del-Pilar-Ruso, Y., Riera, R., 2016. Polychaete/amphipod ratios: an approach to validating simple benthic indicators. Ecol. Indic. 63, 89-99.

De Orte, M.R., Lombardi, A.T., Sarmiento, A.M., Basallote, M.D., RodríguezRomero, A., Riba, I., DelValls, T.A., 2013. Metal mobility and toxicity to microalgae associated with acidification of sediments: $\mathrm{CO} 2$ and acid comparison. Mar. Environ. Res. 96, 136-144.

Eades, C., Waring, C.P., 2010. The effects of diclofenac on the physiology of the green shore crab Carcinus maenas. Aquat. Toxicol. 69, 46-48.

Fabbri, E., Franzellitti, S., 2016. Human pharmaceuticals in the marine environment: focus on exposure and biological effects in animal species. Environ. Toxicol. Chem. 35, 799-812.

Fong, P.P., Ford, A.T., 2014. The biological effects of antidepressants on the molluscs and crustaceans: a review. Aquat. Toxicol. 151, 4-13.

Fonseca, T.G., Morais, M.B., Rocha, T., Abessa, D.M.S., Aureliano, M., Bebianno, M.J. 2017. Ecotoxicological assessment of the anticancer drug cisplatin in the polychaete Nereis diversicolor. Sci. Total Environ. 575, 162-172.

Gagné, F., Blaise, C., 1993. Hepatic metallothionein level and mixed function oxidase activity in fingerling rainbow trout (Oncorhynchus mykiss) after acute exposure to pulp and paper mill effluents. Water Res. 27, 1669-1682.

Gaw, S., Thomas, K.V., Hutchinson, T.H., 2014. Sources, impacts and trends of pharmaceuticals in the marine and coastal environment. Philos. Trans. R. Soc. Lond. B 369, 20130572.

Gélinas, M., Lajeunesse, A., Gagnon, C., Gagné, F., 2013. Temporal and seasonal variation in acetylcholinesterase activity and glutathione S-transferase in amphipods collected in mats of Lyngbya wollei in the St-Lawrence River (Canada). Ecotoxicol. Environ. Saf. 94, 54-99.

Gorokhova, E., Löf, M., Halldórsson, H.P., Tjärnlund, U., Lindström, M., Elfwing, T Sundelin, B., 2010. Single and combined effects of hypoxia and contaminated sediments on the amphipod Monoporeia affinis in laboratory toxicity bioassays based on multiple biomarkers. Aquat. Toxicol. 99, 263-274.

Guitton, J., Souillte, G., Rivière, J.L., Gerard, F., Guilluy, R., Brazier, J.L., 1994. Action of methotrexate on cytochrome P-450 monooxygenases in rats. Study performed with [13C]-aminopyrine micro breath test. Eur. J. Drug. Metab. Pharmacokinet. 19, 119-124.

Hastings, M.H., 1981. The life cycle and productivity of an intertidal population of the amphipod Ampelisca brevicornis. Estuar. Coast. Shelf S 12, 665-677.

Huang, W., Peng, P., Yu, Z., Fu, J., 2003. Effects of organic matter heterogeneity on sorption and desorption of organic contaminants by soils and sediments. Appl. Geochem. 18, 955-972.

James, M.O., Boyle, S.M., 1998. Cytochromes P450 in crustacea. Comp. Biochem. Phys.C 121, 157-172.

Janero, D., 1990. Malondialdehyde and thiobarbituric acid-reactivity as diagnostic indices of lipid peroxidation and peroxidative tissue injury. Free Radic. Bio Med. 9, 515-540.

Jelic, A., Petrovic, M., Barceló, D., 2009. Multi-residue method for trace leve determination of pharmaceuticals in solid samples using pressurized liquid extraction followed by liquid chromatography/quadrupole-linear ion trap mass spectrometry. Talanta $15,363-371$.

Kagan, V.E., Tyurin, V.A., Jiang, J., Tyurina, Y.Y., Ritov, V.B., Amoscato, A.A., Osipov, A.N., Belikova, N.A., Kapralov, A.A., Kini, V., Vlasova, I.I., Zhao, Q., Zou, M., Di, P., Svistunenko, D.A., Kurnikov, I.V., Borisenko, G.G., 2005. Cytochrome C acts as a cardiolipin oxygenase required for release of proapoptotic factors. Nat Chem. Biol. 1, 223-232.

Kennedy, A.J., Steevens, J.A., Lotufo, G.R., Farrar, J.D., Reiss, M.R., Kropp, R.K., Doi, J. Bridges, T.S., 2009. A comparison of acute and chronic toxicity methods for marine sediments. Mar. Environ. Res. 68, 118-127.

Lara-Martín, P.A., González-Mazo, E., Petrovic, M., Barceló, D., Brownawel, B.J., 2014. 
Occurrence, distribution and partitioning of nonionic surfactants and pharmaceuticals in the urbanized Long Island Sound Estuary (NY). Mar. Pollut. Bull. 85, 710-719.

Lara-Martín, P.A., Renfro, A.A., Cochran, J.K., Brownawel, B.J., 2015. Geochronologies of pharmaceuticals in a sewage-impacted estuarine urban setting (Jamaica Bay, New York). Environ. Sci. Technol. 49, 5948-5955.

Maranho, L.A., André, C., DelValls, T.A., Gagné, F., Martín-Díaz, M.L., 2015. Toxicological evaluation of sediment samples spiked with human pharmaceutica products: energy status and neuroendocrine effects in marine polychaetes Hediste diversicolor. Ecotox. Environ. Safe 118, 27-36.

Maranho, L.A., Moreira, L.B., Baena-Nogueras, R.M., Lara-Martín, P.A., DelValls, T.A. Martín-Díaz, M.L., 2014a. A candidate short term toxicity test using Ampelisca brevicornis to assess sublethal responses. Arch. Environ. Con. Toxi. 68, 237-258.

Maranho, L.A., Baena-Nogueras, R.M., Lara-Martín, P.A., DelValls, T.A., MartínDíaz, M.L., 2014b. Bioavailability, oxidative stress, neurotoxicity and genotoxicity of pharmaceuticals bound to marine sediments. The use of the polychaete Hediste diversicolor as bioindicator species. Environ. Res. 134, 353-365.

Martín-Díaz, M.L., Blasco, J., Sales, D., DelValls, T.A., 2004. Biomarkers as tools to assess sediment quality and field surveys. Trac-Trend. Anal. Chem. 23, 807-818.

Martín-Díaz, M.L., Gagné, F., Blaise, C., 2009. The use of biochemical responses to assess ecotoxicological effects of Pharmaceutical and Personal Care Products (PPCPs) after injection in the mussel Elliptio complanata. Environ. Toxicol Pharm. 28, 237-242.

McFarland, V.A., Inouye, S.L., Lutz, C.H., Jarvis, A.S., Clarke, J.U., McCant, D.D., 1999. Biomarkers of oxidative stress and genotoxicity in livers of field collected brown bullhead, Ameiurus nebulosus. Arch. Environ. Con. Toxi. 37, 236-241.

McGuire, J.J., 2003. Anticancer antifolates: current status and future directions. Curr. Pharm. Des. 9, 2593-2613.

Méndez, N., Lacorte, S., Barata, C., 2013. Effects of the pharmaceutical fluoxetine in spiked-sediments on feeding activity and growth of the polychaete Capitella teleta. Mar. Environ. Res. 89, 76-82.

Meredith-Williams, M., Carter, L.J., Fussell, R., Raffaelli, D., Ashauer, R., Boxall, A.B.A. 2012. Uptake and depuration of pharmaceuticals in aquatic invertebrates. Environ. Pollut. 165, 250-258.

Norberg-King, T., 1988. An Interpolation Estimate for Chronic Toxicity: the ICp Approach. Technical Report. National Effluent Toxicity Assessment Center, pp. 05-88.

OECD, 2000. Adsorption - Desorption Using a Batch Equilibrium Method. Guideline, p. 106

OECD, 2004. Sediment - Water Chironomid Toxicity Test Using Spiked Sediment. Guideline, p. 218.

Olive, P.L., 1988. DNA precipitation assay: a rapid and simple method for detecting DNA damage in mammalian cells. Environ. Mol. Mutagen 11, 487-495.

Pérez, E., Blasco, J., Solé, M., 2004. Biomarker responses to pollution in two invertebrate species: Scrobicularia plana and Nereis diversicolor from the Cádiz bay (SW Spain). Mar. Environ. Res. 58 (2-5), 275-279.

Pires, A., Almeida, A., Calisto, V., Schneider, R.J., Esteves, V.I., Wrona, F.J., Soares, A.M.V.M., Figueira, E., Freitas, R., 2016. Hediste diversicolor as bioindicator of pharmaceutical pollution: Results from single and combined exposure to carbamazepine and caffeine. Comp. Biochem. Phys. C 188, 30-38.

Poppe, L.J., Eliason, A.H., Fredericks, J.J., Rendigs, R.R., Blackwood, D., Polloni, C.F. 2013. Chapter 1: Grain-size analysis of marine sediments: Methodology and data processing. In: United States Geological Survey Open-File Report 00-358. Available at: http://pubs.usgs.gov/of/2000/of00-358/text/chapter1.htm. accessed 13.03.17.).

Quinn, B., Gagné, F., Blaise, C., 2004. Oxidative metabolism activity in Hydra attenuata exposed to carbamazepine. Fresenius Environ. Bull. 13, 783-788.

Quinn, B., Gagné, F., Blaise, C., 2008a. An investigation into the acute and chronic toxicity of eleven pharmaceuticals(and their solvents) found in wastewater effluent on the cnidarians. Hydra Attenuate. Sci. Total Environ. 389, 306-314.

Quinn, B., Gagné, F., Blaise, C., 2008b. The effects of pharmaceuticals on the regeneration of the cnidarian Hydra attenuata. Sci. Total Environ. 402, 62-69.

Rader, J.I., Huennekens, F.M., 1973. Folate-coenzyme-mediated transfer of onecarbon groups. In: Boyend, P.D. (Ed.), The Enzymes, vol. 9. Academic Press, New York, pp. 197-223.

Regoli, F., Giuliani, M.E., 2014. Oxidative pathways of chemical toxicity and oxidative stress biomarkers in marine organisms. Mar. Environ. Res. 93, 106-117.

Rewitz, K.F., Styrishave, B., Løbner-Olesen, A. Andersen, O., 2006. Marine invertebrate cytochrome P450: Emerging insights from vertebrate and insect analogies. Comp. Biochem. Phy. C 143, 363-381.

Riba, I., Casado-Martínez, M.C., Forja, J.M., DelValls, T.A., 2004. Sediment quality in the Atlantic Coast of Spain. Environ. Toxicol. Chem. 23, 271-282.

Santos, L.H.M.L.M., Araujo, A.N., Fachini, A., Pena, A., Delerue-Matos, C., Montenegro, M.C.B.S.M., 2010. Ecotoxicological aspects related to the presence of pharmaceuticals in the aquatic environment. J. Hazard. Mater 175, 45-95.

Schlenk, D., Celander, M., Gallagher, E.P., George, S., James, M., Kullman, S.W. VandenHurk, P., Willett, K., 2008. Biotransformation in Fishes. In: Di Giulio, R.T. Hinton, D.E. (Eds.), The Toxicology of Fishes. Taylor and Francis, New York, pp. $153-234$.

Silva, C., Mattioli, M., Fabbri, E., Yáñez, E., DelValls, T.A., Martín-Díaz, M.L., 2012. Benthic community structure and biomarker responses of the clam Scrobicularia plana in a shallow tidal creek affected by fish farm effluents (Rio San Pedro, SW Spain). Environ. Int. 47, 86-98.

Site, A.D., 2001. Factors Affecting Sorption of Organic Compounds in Natural Sorbent/Water Systems and Sorption Coefficients for Selected Pollutants. A Review. J. Phys. Chem. Ref. Data 30 (187). http://dx.doi.org/10.1063/1.1347984.

Solé, M., Kopecka-Pilarczyk, J., Blasco, J., 2009. Pollution biomarkers in two estuarine invertebrates, Nereis diversicolor and Scrobicularia plana, from a Marsh ecosystem in SW Spain. Environ. Int. 35, 523-531.

USEPA, U.S., Environmental Protection Agency, 1994. Methods for Assessing the Toxicity of Sediment-associated Contaminants with Estuarine and Marine.

USEPA, U.S., Environmental Protection Agency, 2001. Methods for Collection, Storage and Manipulation of Sediments for Chemical and Toxicological Analyses: Technical Manual. EPA/823/B-01/002. US Environmental Protection Agency, Washington, DC

Van der Oost, R., Beyer, J., Vermeulen, N.P.E., 2003. Fish bioaccumulation and biomarkers in environmental risk assessment: a review. Environ. Toxicol. Pharm. 13, 57-149.

Van Gestel, C.A.M., Van Brummelen, T.C., 1996. Incorporation of the biomarker concept in ecotoxicology calls for a redefinition of terms. Ecotoxicology 5, $217-225$.

Wills, E.D., 1987. Evaluation of lipid peroxidation in lipids and biological membranes. In: Snell, K., Mullock, B. (Eds.), Biochemical Toxicology, A Practical Approach. IRL Press, Oxford, pp. 127-150. 